\title{
The influence of geopolitics and strategical factors upon the development of natural and human resources in Indonesia
}

\author{
Ukar Wijaya Soelistijo \\ University of Islam Bandung, Institute of Technology Bandung, Mineral and Coal Technology R\&D Center, Bandung Indonesia
}

\section{Email address:}

ukar@tekmira.esdm.go.id, ukarws@yahoo.com

\section{To cite this article:}

Ukar Wijaya Soelistijo. The Influence of Geopolitics and Strategical Factors upon the Development of Natural and Human Resources in Indonesia. Social Sciences. Vol. 2, No. 6, 2013, pp. 200-211. doi: 10.11648/j.ss.20130206.15

\begin{abstract}
The understanding of geopolitics based on the Nusantara outlook (Wawasan Nusantara), Indonesia requires to raise the effort of mastering and developing technology which has roots in the nation's culture as an important means of national productivity hop towards resulting qualified and global competitive national products achieving national prosperity and security at the utmost and such universal humanity as a whole in an enduring peace of world. In the meantime genuine nation's human being are required as productive people with fully innovative and creativity, reliable mental and noble morals. At the level of Nusantara outlook, the understanding of expansion might be able to interpret as an social-economic one for the prosperity of humankind at the utmost, and not in the meaning of orthodox geopolitics. The aim of this article is to briefly study the influence of geopolitics and other strategic factors upon the development of natural and human resources in Indonesia. The main aspects of the study is concenrned with future potential prospect of human and natural resources in Indonesia that should be developed for the wealth of the Indonesian people at the utmost by considering the global strategical environment and under the Nusantara outlook. This study is carried out by using methods of geopolitics, science and technology, and global competition approaches as strategic factors which influence upon human and natural resources development toward creating the wealth, intelligence and peace of the people.
\end{abstract}

Keywords: Geopolitics, Strategical Factors, Natural and Human Resources

\section{Introduction}

Within the understanding of geopolitics based on Nusantara outlook, Indonesia necessarily increases the effort of mastering and developing technology to gain the added value of the national resources which is rooted on our nation's culture as an important instrument on creating qualified and high global competitive national productivity jump in achieving national prosperity and security and the whole human kind universally within the eternal peaceful world (Anonymous (b), (c), (f), 2000). Therefore, a respectful nation's human kind as an opus person is who has innovative power and high creativity, viable mental and noble moral. The four pillars of Nusantara outlook is consisted of Pancasila as the basic philosophy of the Indonesian people, the 1945 Constitution, concept of diversity but unity, and the Unity State of Republic of Indonesia.

The aim of this article is to briefly study the influence of interaction between geopolitics - science and technology and global competition upon the development of natural and human resources in Indonesia.

Indonesia is blessed large natural and human resources. Natural resources are consisted of renewable and non-renewable resources. Renewable resources may include such as forestry, plantation, fishery, agriculture, livestock and especially in the field of energy for instance, solar, ocean tide, biomass, geothermal etc. Non-renewable resources are for instance, minerals, oil and gas, coal and rocks. Transfering those natural resources into economic capital and then finally into social capital, the competent and intellectual human resources as human capital are absolutely required. Moreover, the human capital who has been mastering science and technology as one of the social capital could carry out sustainable development toward producing goods and services required by the people achieving their wealth, intelligence and peacefulness of life.

Concerning with the natural resources, the problem is that its distribution among the region is not equal, but every 
people needs it to satisfy their needs of life.

Furthermore, in the system of natural resource development toward achieving national goal there are five sub-systems, e.g., governmental sub-system that concerns with policy and regulation, regional sub-system concerns with regional development, industrial sub-system concerns with production-consumption or supply-demand, international sub-system concerns with global competition and relationship such as trade and investment, and last but not least science and technology sub-system concerns with knowledge, technological change and productivity. This integrated system of natural rresource development system is composed toward achieving the national goal under the condition of national resilience.

\section{Methodology and Theory}

Theory and methodology of observation of the interaction of the above three main factors of geopolitics, science and technology, competitiveness is assessed as the followings based on descriptive and qualitative instrument.

\subsection{Geopolitics}

Geopolitics is a knowledge based on the anvil of basic thought or concept of "lebensraum", theory of national power, theory of leadership, laws of organism, deterministic including theory of economy which is very dynamic and integrative. The viability of a nation in supervising geopolitics can cause as an expansionist. Political geography means as a linkage between meaning, value and influence of geography on politics based on the consideration of benefit and loss toward the national interest of a nation, in this case of the national security and prosperity interest as the most important matter. The study on science of geography and its linkage with politics and strategy of a nation constitutes and as a very vital matter. The presence of a deterministic approach causes the emergence of extreme opinion which may states that geography determines national politics and strategy. Moreover, everything is heavily influenced by change, dynamics, time, location and condition. The above condition of thought tends to carry out an expansion or practices of imperialism (Anonymous (b), (c), 2000).

\subsection{Science and Technology versus Human Resource}

Science and technology as one of the strategic factos contributes three important anvils in the social life, i.e. (a) science and technology offers anvil of life in the form of satisfying basic needs of the society; (b) science and technology put up possibility on a system of information and communication in micro and macro evaluation and analysis of the whole society; (c) healthy and prosperous human being who is rich of information will be quickly utilizes and develops all the required science and technology to improve his fate and upgrade his quality of existence (Anonymous (d), (e), 2000; Soelistijo, 1990; Habibi, 1988).

\subsection{Global Competition}

To be able to create optimal productivity with the global competitive advantage, principally qualified and energetic or innovative human resource is required where it is also supported by engineering science and viable industrial management. The innovative human resource characterized by high content of knowledge, competent, experience and motivation, therefore, is able to catch business opportunity in creating new materials, goods and service product besides improving process and method of new delivery toward just on time delivery (Anonymous (c), 2000; Bressand, 1991).

All in all, facing the future Indonesia should have national resilience in terms of ideology, politics, economy, social, culture, security and defense to overcome the eternal threat, hindrance, obstruction and challenges. Presently, at the international as well as regional level, Indonesia has been at the position as part of the solution and not just as part of the problem in those above spectrums in the international community intercourse such as ASEAN, East Asia, APEC, and UN or global. In principle, many concepts of development of how to create the sustainable condition in term of the people's power of endurance, absorbtion and competitiveness based on the strategy of pro-growth, pro-equity, pro-environment and pro-poor toward achieving wealth, intelligence and peacefulness of mankind, Indonesia could utilize her strategic geographical and geopolitical posisiton located between two continents those are Asia and Australia, and two oceans of Pacific and Indian Oceans. Indonesia archipelago has three sea links of communication (SLOC) of (1) acrossing Indian Ocean-Sunda Strait-Java Sea-Karimata Strait-Malaca Strait-South China Sea and Pacific Ocean, (2) acrossing Indian Ocean-Lombok Strait, Java Sea-Makassar Strait-Pacific Ocean,(3) acrossing Indian Ocean-Maluku Sea-Pacific Ocean. Then she could utilize these SLOCs to develop connectivity supporting the Indonesian Master Plan of Accelerating and Expanding Economic Development 2011-2025 (Figure 2.1) (Anonymous (j), 2011). This mindset requires grand concept to analyze Indonesia development based on geopolitics and other srategical factors such as science and technology, global competition and national multiple mangement system.

The methodology of this study is unique because of its concerns with the above-mentioned pro-growth, pro-equity, pro-poor and pro-environment as a whole. Since pro-growth concerns with the national economic growth then the total output of national income is distributed over regions through regional development mechanism. Regional development is pro-equity that pertains to the equitable distribution of the development activity and output of development over regions to gain socisl-economic convergence across-regions. Pro-poor is interested in eluviating poverty in the country through carrying out regional development and social safety net. Pro-environment is to perturb with the global environment toward achieving to meet with the need of people's live in pleasant environment. As a whole the natural 
and human resource development is directed to create the people's live with green social-econmic condition.

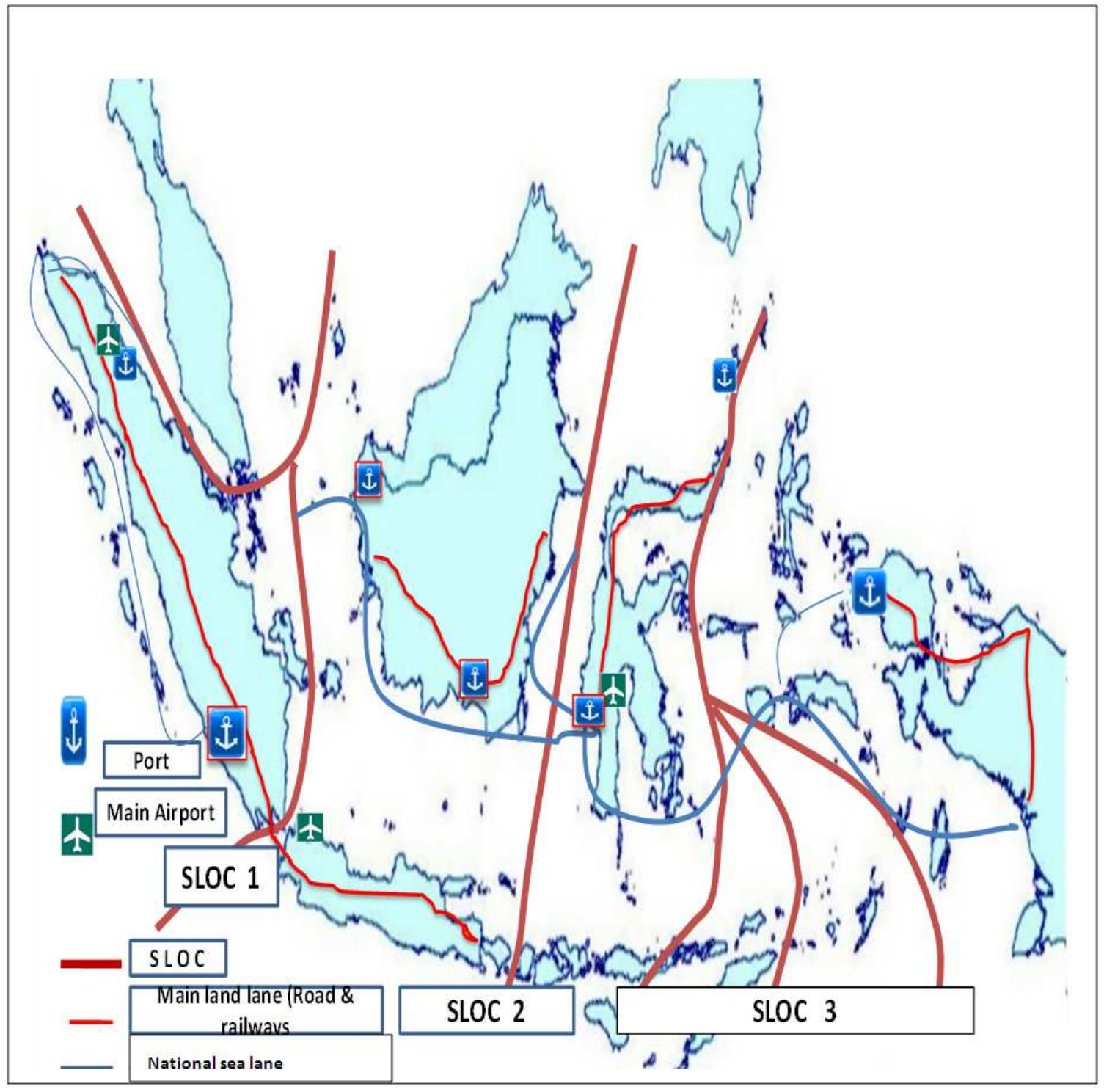

Figure 2.1. The relationship between SLOC and the Indonesian corridor connectivity across-regions

\section{Discussion - the Results of Observation and the Forward Steps}

The national strength constitutes as product of national resilience as instrument of struggle for realization of desire that is intrinsically linked highly with location, climate, topography, wide, form and character of land, natural resources, and the matter of human resource quality that may include capability, level of culture and their civilization, which may constitute their vital weight upon condition and relationship between across countries and the development of nation and country.

In the case of the Indonesia nation, the above concept of thought or desire which tends to be expansionist or imperialist is obviously not suitable with her philosophy of life. It looks likely that the politics and strategy of Wawasan Nusantara (Nusantara outlook) is more suitable as the
Indonesian geopolitics and strategy, because it shows the continuity and consistency of the mindset in the case of the anvil of the philosophy of the nation and country as the rooting of Pancasila and the 1945 constitution as well (Anonymous (b), (f), 2000).

In fact, in this context it can be stated that geography does not influence or create the condition of politics and strategy per se. Thing that can affect is the knowledge and idea which is taken from the knowledge of geography that can affect and create the condition of formulating the national political strategy. In the case of Indonesia, the thought of conception is ought to have the base of Pancasila and the constitution of 1945 , in which the national interest and the aim of the struggle of the nation is formulated. Moreover, it is based on the study on multidisciplinary analysis that it is characterized by a universal scientific objective and it is also based on the investigation of the nation history and also other science and factors on the related fields of formulating 
politics, strategy, either for its formulation or for the development of the whole fields and formulating the precise foreign policy to support the national development.

Several results and forward steps that are required to anticipate in order to the national product having global competitive power in the condition of the developing geopolitics, among others, are:

a Increasing excellence quality of the Indonesian human kind.

An identity of a nation could be firmed through continuous capacity building on the quality of humanity to reach the excellence rank by spirit training, struggle spirit, eagerness, capability through various education and training systematically. Any nation either the developed or the lagged one, at the present time they still need high national spirit, so that any nation humanity could become an opus person with a viable mental and moral as well.

b Mastering in technology development.

Technological change due to mastering technology development and high ability of industrial management is the very important thing in the role of economizing production cost maintaining and increasing the quality of the resulted goods and services (Figure 3.1) (Soelistijo, (2003), including in the case of product differentiation all at once in lieu with the market taste. Besides, it should also be able to arrange the inward and outward enterprise integration to manage production function as well.

In other words, through innovative human resource would result high competitive output in the meaning of quality and the lowest cost of production and continuous supply and time (just in time delivery).

- Formal education lane in the frame of struggling and creating "own" technology requires support of political will from the developed countries for the transfer of technology without certain pre-requisite. Even, in principle the transfer of technology per se is hardly happened, because it would pass through very long path and phases of technological analysis, social-economic and social-political analysis as well.

- $\quad$ Readiness for technological mastering.

In a formal meaning that it should have had an existence of the institutions at the central as well as at the regional level. At the sense of material, it means that: (a) it should be studied from the various existence i.e. culture, geographical location, environment; (b) education gab between municipal community and rural one; (c) be forced to accept technology due to prestige, status, position or demonstration effect; and (d) requires change of community attitude at a whole.

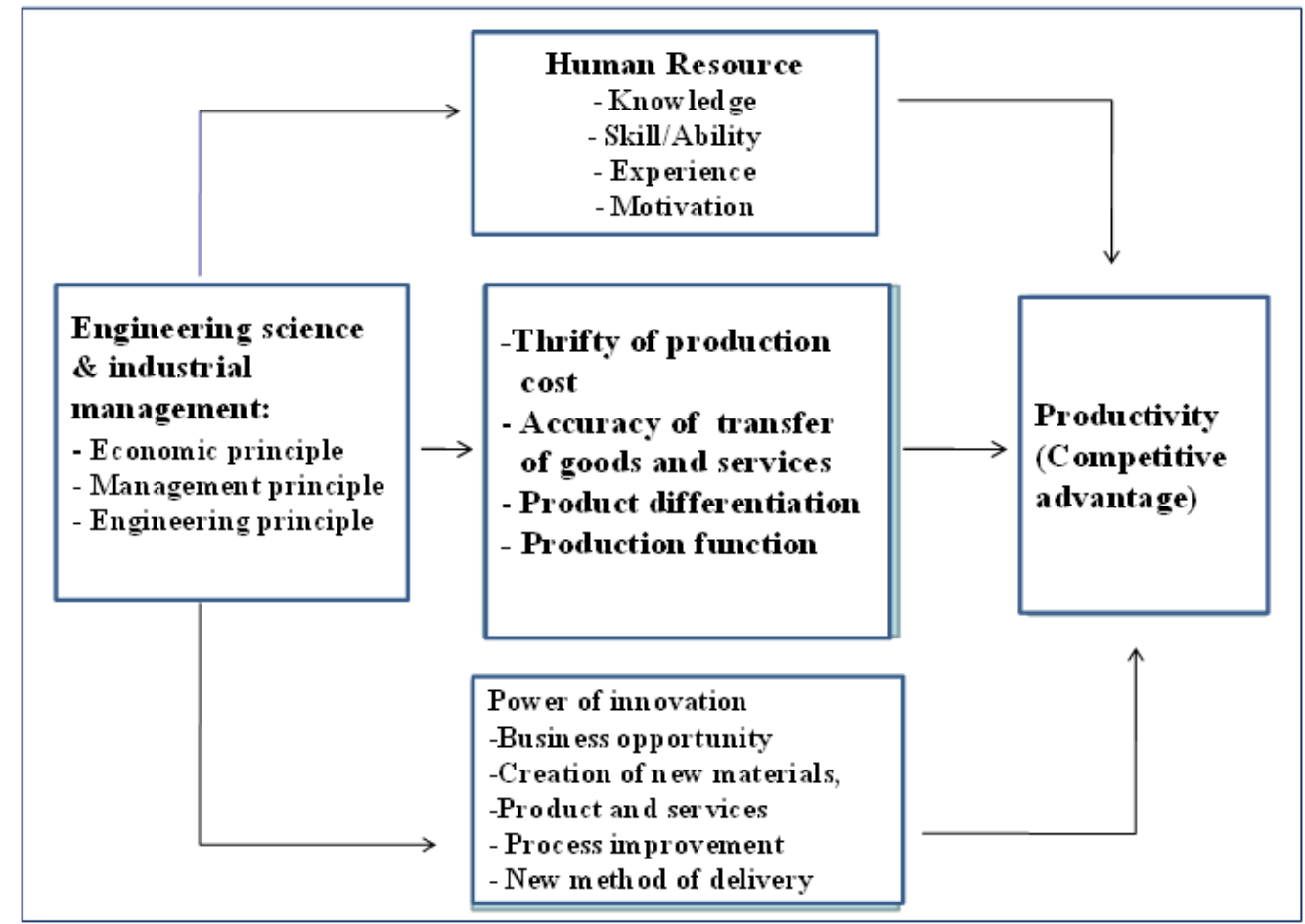

Figure 3.1. Linkage between quality of human resource, engineering science and industrial management, and product competitiveness

Conditional and selective spur through the understanding of: (a) downward-upward communication; (b) technology use in accordance with the every regional interest and capability; (c) science and technology do not satisfy the thin layer of the community and its use is not free of value; and (d) technological application is rationally considered. Mastering technology is more focused on "core technology" and not on "peripheral technology." Mastering technology at the level of capability or "do how stage" is necessarily pushed to the level of creating capability or "know why".

At the level of operational capability up to adaptation of upgrading technology is necessarily directed on "consumption technology" and moreover on "production technology." 


\section{- Technology innovation}

The progress of technology should be continuously fostered and developed, fore instance in the field of bio-technology (overcoming the problem of food through increasing the production of commodity and increasing the quality of land, overcoming negative impact of industrial waste; suppressing production cost; developing the mining of natural oil by using EOR through biogenic); ceramic for super conductor (yttrium, rare earth); and mechanics-electronics - as fusion of ceramic and electronic (office automation by using computer/internet/electronic camera/video camera).

- Transfer of technology, mainly of appropriate technology that is directly able to solve the problems which acutely faced and burdened by the wire spread community, such as

$=$ the cronical problem of garbage by using the development of solar power plant, biomass and or biogas made from garbage;

$=$ the problem of green house effect resulted from the incompletee combustion in the region of micro-, small-, and medium industry, and so on.

- Law instrument is required with the completeness of procedure, method, criteria, decision and operational program.

- Even at the present time there is law of IPR (intellectual property right-patent, however the response of the community of creation is still low. This law is only fortunate the foreigner who sells many technological products to us.

- The mechanism of cooperation across-enterprises, the institution of R\&D and the universities.

- The system of technology information, on technological specification of certain technological instrument that is easily earned by the community such as relating to type of technology, the creator, specification of technology, location to find out it including its economic variables (price, operational cost, its viability) and so on, in order the community becomes technology minded.

c. Creating management of technology until producing the humankind with high content of science and technology in the era of industry to solve various problems faced by the nation as well.

Science has a source from culture and then it should be related to culture as well. Science and technology which does not take root on culture would create unpredictable problem and could conflict with the process of added value, even would decrease productivity of implementation of added value implementation. Process of added value would be happened if there is no technology per se and its change of technology. Technology would not be developed if there is no science, and both should have root on the main values and element of culture.

In lieu with the base and soul of the 1945 constitution as the national reference, so that at the higher rank, the development of science and technology is purposed to support achievement of national goal, and at the lower level it is directed to increase productivity of the whole resources as the input factor of the production processes.

Technology as the effort of increasing added value is necessarily supported by positive cultural environment, e.g. human resource who has the creative spirit, innovative and future outlook with also considering natural condition and its benefit for the prosperity of the Indonesian people.

To achieve the above target and in facing a new technology order, a comprehensive and transparent policy and program of science and technology is required. The government policy that more emphasizes research and development activity to develop basic and applied science in the past it seems that the involvement of the industry is very poor. It is just exactly on account that the industry constitutes a locomotive of science and technology development, and they are all at once as the competent consumer of technology as well. Therefore, innovation policy at the macro level that inviting the industry involvement in the activity of technology innovation in the field of industrial technology, engineering, and applied research for commercial purposes, while at the micro level the management of technology is required.

In the management of technology, measurement and its utilization is required through evaluation of its technological map (Anonymous (e), 2000; Soelistijo, 1990, 2003). Evaluation on its position and the attained result by using international benchmark from the lower ranking up to the higher one. A technological map can be developed as the gauge of the science and technology development. Technological map is the method to measure mastering of technology at the macro as well as at the micro level to design and determine technology policy. The component of technology map, among others are techno-ware human-ware, and info-ware. The system of evaluation can be based on technology content added (TCA), economic value added (EVA), and technology content coefficient (TCC).

- Evaluation on strength and weaknesses on investment effort in the frame of optimization of scarce resource. ESWOT analysis (Environmental Strength Weaknesses Opportunity and Threat) is required as inward looking and outward looking as environmental outlook that could create an investment in the form of productivity jump with the competitive output which resulting profit to the investor as well as to the national interest.

- Implementation of management by objective (MBO), in the case of quantification on the target achievement and its motivation. Of course $\mathrm{MBO}$ is necessary required in term of goal oriented, even though is truly also concerned with its process of how to achieve the goal (management by system/MBS) in order not out of law and rule of the game per se.

- Planning, organizing, actuating, controlling and evaluating (POACE) on the performance of technological change. So that, the process of achieving the goal in the management of technology in a spiral 
manner of management upon cycle by cycle of POACE in order to achieve target between activities and the final activity towards final target and aim that is growth of national productivity (Figure 3.2).

Moreover, to anticipate transformation of science into technology several steps are required, among others application of the bases and technology management techniques into technology by the easy and clear method, and pushing the awareness of technology manager upon utilization of the available instrument and professional development.
Going through the above steps is expected that the technology management could achieve the target of national development in the field of science and technology faster, in order to support achievement of national productivity growth performance (Figure 3.2) (Habibi, 1988). Of course, in this implementation of technology management, massive coordination in the research and technology between Minister of Research and Technology, university, Ministerial/Non Ministerial Agency for R\&D and private $\mathrm{R} \& \mathrm{D}$ is absolutely required.

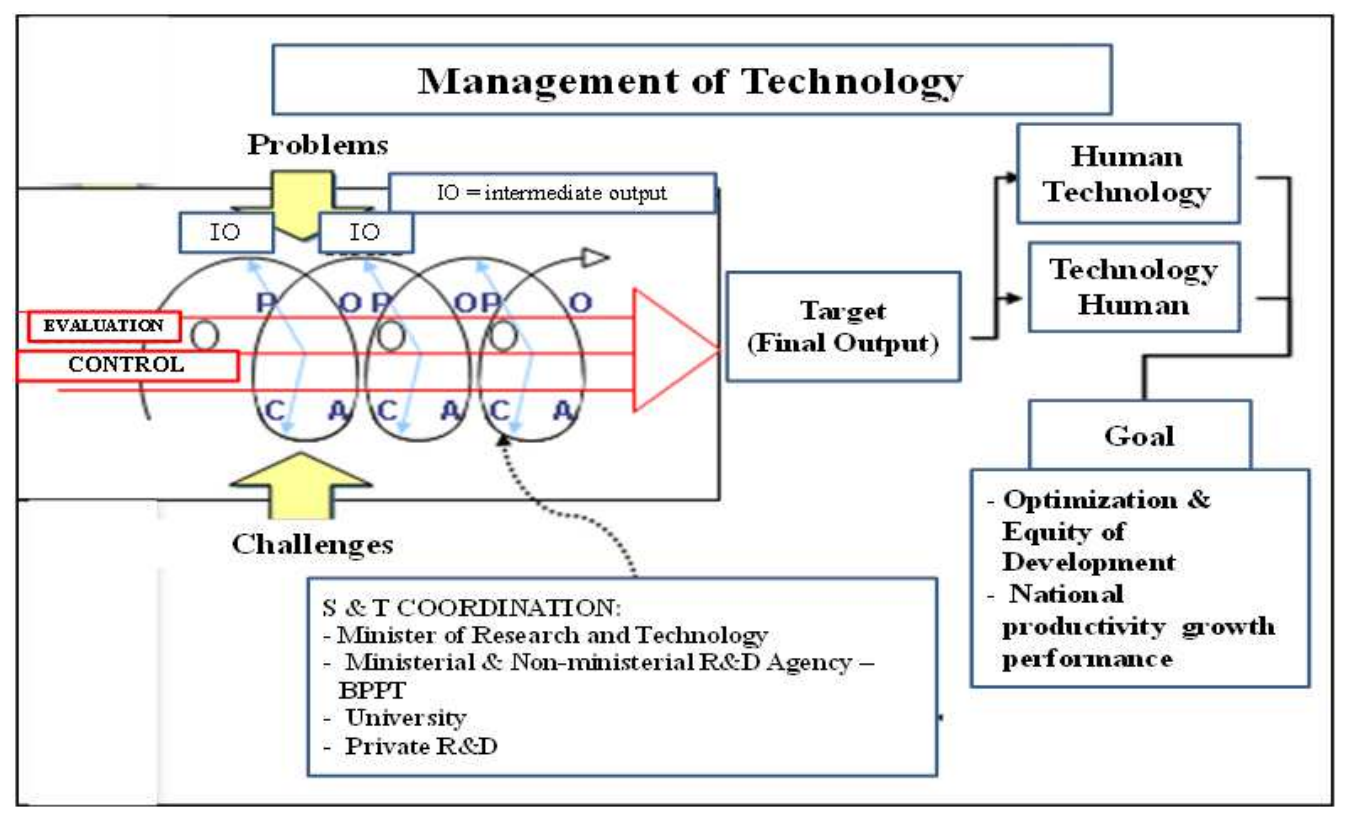

Figure 3.2. Process of technology management in the achievement of national productivity growth performance

The examples of various problems of the nation from the upstream, mediation, to downstream, among others, are as the followings:

i The quality of the nation human being that is still apprehensive about and then it is necessarily required to be a competent human being and high competitiveness.

ii Lack of domestic water in the dry season, flooding in the wet season due to not owning of conservation spirit, reforestation, utilizing water absorption areas.

iii Importing food including meat, qualified fruits, toward mastering food technology or biotechnology in the large meaning. The King of Thailand uses his personal funds to do research and development in the field of agriculture, until we also learn and enjoy the products with the so-called the qualified Bangkok-papaya, -durian, and the other kinds of fruit.

iv How many millions of sacrifice animals at the Idul Adha day, and at the other side Australia is doing the development business these sacrifice animals at the large scale in Western Australia. Why we do not consider to response this matters creatively?

$\mathrm{v}$ Importing the industrial raw materials including minerals, livestock feed toward developing downstream technology to increasing the added value domestically.

vi A lot of unemployment, toward utilization of natural resource in the development based on resource based development, that in reality our country is very resourceful to create employment in the field of natural resource development.

vii With the declining of metallic material, anticipation of developing material recycling technology is required.

viii Development of waste technology for supporting e.g. waste electric power generating, biomass etc.

ix Development of technology of new and renewable energy.

$\mathrm{x}$ And other kind of technology either upstream- , downstream-technology, or distribution and communication technology that will be very useful for developing our archipelago state which has large national resources to mate with the other non-national resources for the purpose of the prosperity and security of nation and state at the utmost.

In Indonesia the various advanced science and technology 
have been applied in the field of mining and energy, for instance:

- In the field of copper mining of PT Freeport Indonesia in Papua and of PT Newmont Nusa Tenggara, coal mining of PT Kaltim Prima Coal (KPC), PT Adaro, PT Arutmin in Kalimantan, so that the minimum production cost or the lowest cost in the world is obtained. It means that those mines have applied the most efficient process of production. These companies have gained the windfall profit as the result of the tremendous increasing world market price of their mineral commodities (the increase of doubling and tripling) such as gold, copper, tin and coal (Anonymous (i), (1995); (g), 1997-2000; (h), 1999; Soelistijo, 2012).

- The development of coal liquefaction of Bukit Asam coal, Berau and Arutmin coals through the cooperation between Indonesia and NEDO Japan, which shows the possibility of its commercialization facing the lack of oil in the near future, where Indonesia faces as net oil importer within this decade. (Soelistijo, 2012; Soelistijo et al, 2003). In the early of the year of 2000 (Soelistijo et al, 2003, 2008) the result of coal liquefaction with the production cost of around US\$ 22-23 per barrel was very closed to the world oil price at that time. And it is assumed if the price of oil reached US\$ 35 per barrel, then coal liquefaction would be economically feasible. And then what happened, the present oil price has reached above US\$ 70 even ever higher than US\$ 100 per barrel, however the implementation of the Indonesia coal liquefaction has not been carried out yet, while it would loose the momentum of the "golden" opportunity.

- In the field of oil mining of PT Caltex Pacific Indonesia in Riau (presently is PT Chevron) it can increase the recovery of oil mine by using enhanced oil recovery.

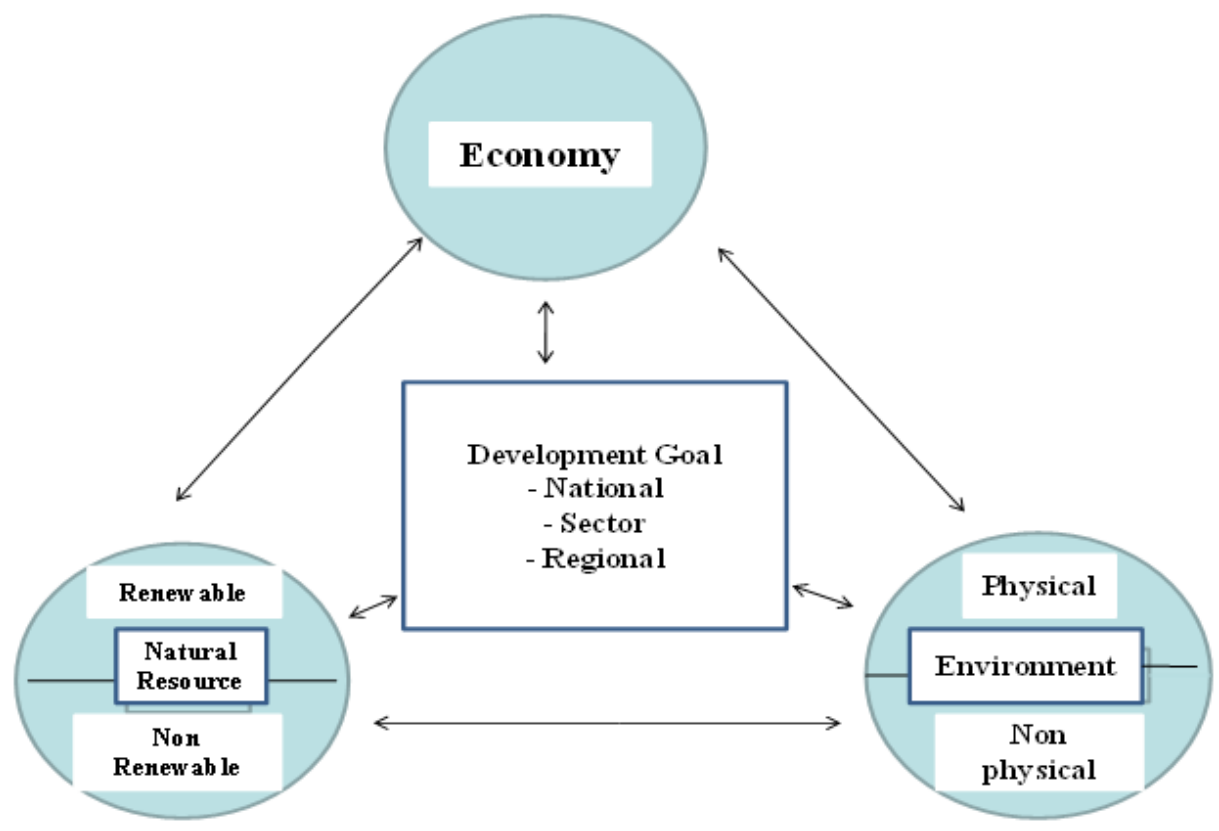

Figure 3.3. Interaction between management of natural resource utilization-economics - environment in the context of achievement of development goal

Based on the above various examples could be stated that once it is anticipated to utilize the natural resource including mineral and tranfering to become economic capital, then the problem of managing and caring the environment should be noticed in the context of physical and non-physical environmental-based development (Figure 3.3) including the technologigal management that should be environmental friendly. Physical environmental development may include land rehabilitation such reclamation and revegetation during the mining period and within the post mining one. Non-physical environmental development could cover the socio-ecoconomic-cultural development including creating job and income for the local people who live within the surroundings of the mine sites in the every regions in the country. Automatically, the cost of environmental management and protection should be included as an integral part of process of transferring natural resources. Above all, at the present era and on it has been stipulated that climate change caused by the global warming should be solved as an integral part of the development in every country and as well as global.

In principle, environment as one part of resources in the production function formulation:

$$
\mathrm{Y}=\mathrm{f}(\mathrm{K}, \mathrm{L}, \mathrm{R}, \mathrm{E}, \mathrm{I}, \mathrm{Mr}, \ldots . .)_{\mathrm{T}}
$$

so that a system of management (POACE - planning, organizing, actuating, controlling and evaluating) of each production function reource is required as a whole (Figure 3.4). In this case it may include the resource of capital (K), human or labor (L), natural (renewable and non renewable), environment $(\mathrm{E})$, information (I), market (Mr), and last but not least technology $(\mathrm{T})$, in the purpose in order to utilizing 
all the various resources could be able to result optimal output, and efficiently, effectively and economically, and Y is output in the form of national income (GDP) as the accumulation of the value of goods and services produced every year. In this case, the meaning of management is"management of management" or figured out as the"matix of management function" or "POACE of POACE or multiple management" (Figure 3.4). Moreover, the development goal as stipulated in the preambule of 1945 Constitution may cover welfare, intelligence, and peace of the people. These aims, at the national level and regional one, could be achieved in the forms of such as sustainable economic growth as the output of the whole economic sectors and sustainable regional development progress as the result of equitable distribution of development over regions and over time.

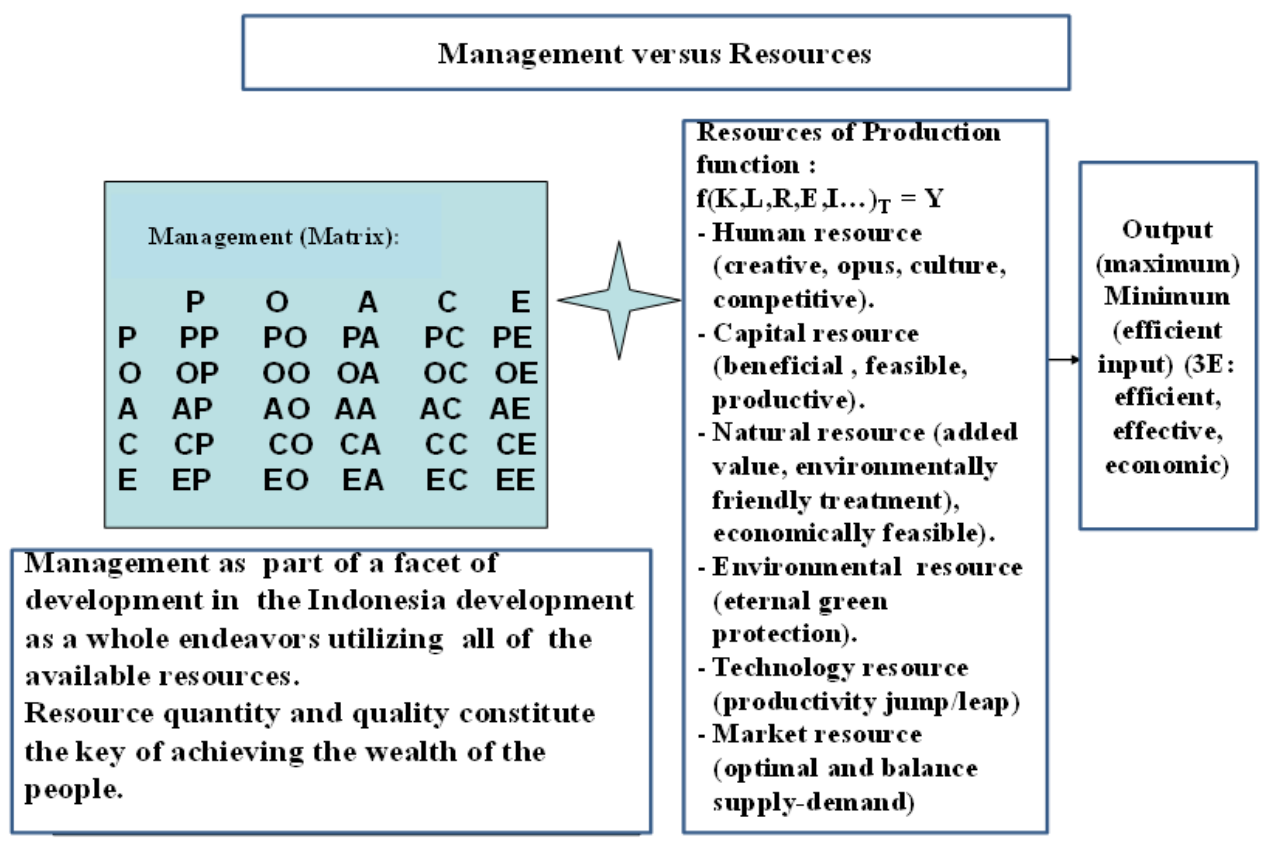

Figure 3.4. Scheme of resource management in the production function

Resource management constitutes as one of the development facet in the purpose of Indonesia development as a whole (Figure 3.4). The matrix management or multiple management of resources should be carried simultaneously and continously. It means that for human resource management is to create cometitive human capital in terms of creativity, opus, cultural-oriented and competitive. For capital resource management is to provide and utilize it in creating feasibility, productivity and benefit for the people. For natural resource management is to inventorise, develop conserve and utlize it for the wealth of the people at the utmost. For environmental management is to guarantee the eternal green protection. The management of technology is to develop technology of creating productivity jump. And management of market is to facilitate the transaction between supply and demand in the purpose of sustainable economic growth. As a whole, the purpose of management of resources is to guarantee sustainable economic dvelopment by te principle of efficient, effective, and economical toward producing optimal output. The problem of resource management constitutes as part of the Indonesia development problem in the case of its utilization effort. Indonesia owns large amount of various natural resources that is available land, water and even in the air even though it has not well managed yet then the majority of the Indonesian people are still in the condition of poverty.
Especially, in the case of natural resource management (Anonymous (a), 1988; Reksosoemitro, 1992; Soelistijo, 1993, 2005, 2013; Anonymous (h), 1999) it is necessary implemented based on the systematical factors of inventory, development, utilization and enterprising, marketing and conservation (Figure 3.5). Intensive inventory is necessary carried out through various grass root exploration activity to recognize its quantity, quality, and distribution of location, then to utilize its detail information as input into forward planning in the grand strategy systematically for the national interest in particular for the wealth of the people at the utmost.

More specific, the importance of science and techmology management should be handled in more focus to achieve its mastering (Figure 3.2) (Soelistijo, 1990). Since in the term of science and technology mastering for a nation is compulsory then she could be fully creative to face her future with full self-trust-and-relience shown as two faces of a coin those are technology devoted to people at one side and people who contains massive technology at the other side that is so called as "technology human" or "technological people" and "human technology". Technology human is human resource who has high content of science and technology and human technology is technology that has devotion to the wealth of the people and vice versa. By supervising science and technology (S\&T) as the only way 
how to create possibility on resource productivity jump for os material, and other various resources (Figure 3.6). instance productivity of capital, of labor, of natural resource

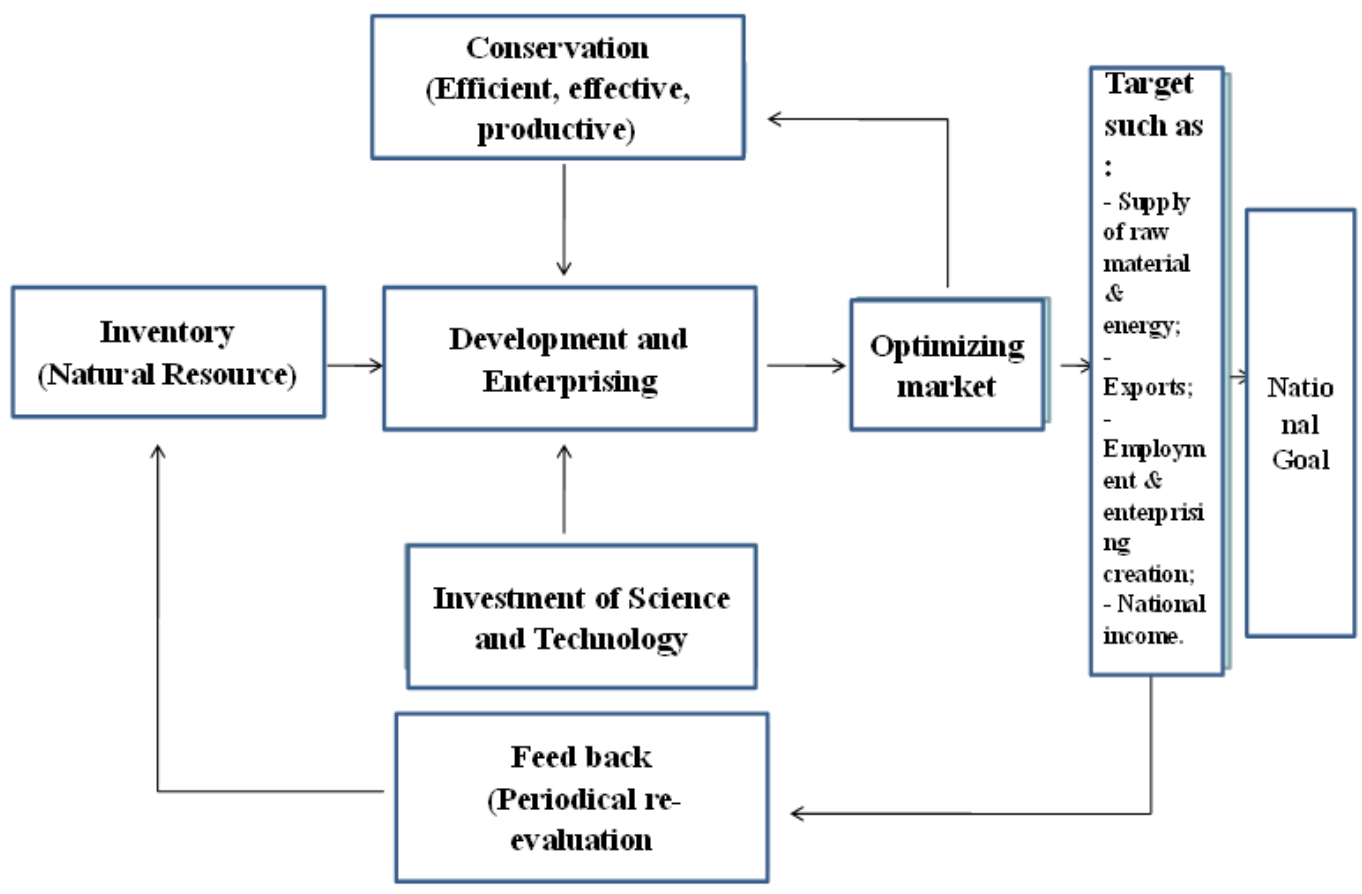

Figure 3.5. Basic management of natural resources

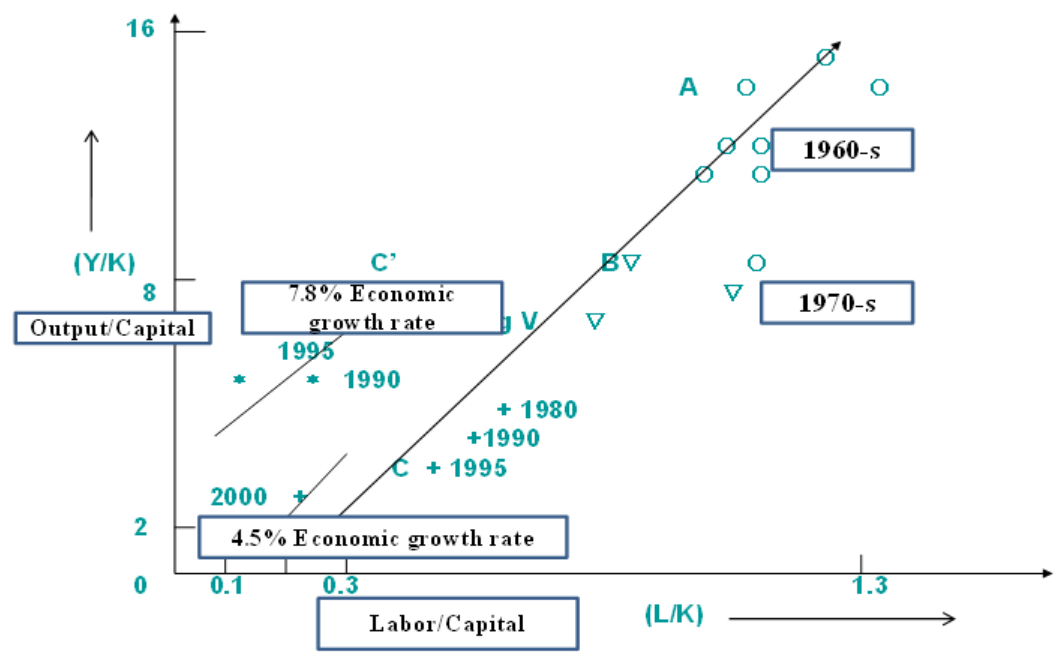

$Y=$ Gross domestic product; $K=$ capital input; $L=$ lab or input; $L / K=1$ abor $/$ capital ratio; $\mathrm{Y} / \mathrm{K}=$ Output/capital ratio or capital productivity

Figure 3.6. Graph of capital productivity $(Y / K$ versus $L / K)$ in the Indonesia econony(1960-2000)

Based on prediction graph of capital productivity in the Indonesia economy (Sollow, et al, 1961; Soelistijo, 1978), it can be shown that there was a declining capital productivity within the years of 1960-s toward the year of 2000 (Figure 3.6), even though the economic growth rate was increasing, in line with the ever absorption of technology in the various economic sectors. While the absorption of technology application has not affected yet achievement of productivity jump in this case capital. At the level of $(\mathrm{L} / \mathrm{K})$ around 1-1.3 with at the level of capital productivity $(\mathrm{Y} / \mathrm{K})$ of around
15-16 in 1960-s was declining down to $(\mathrm{Y} / \mathrm{K})$ around 2.0 at the level of $(\mathrm{L} / \mathrm{K}) 0.1$ (Soelistijo, 1978, 1984). This result of prediction is actually not far from the current reality. The current study shown that in the regions where there are activities of high-technology large scale companies such as PT INCO in Luwu Timur Regency and geothermal power plant of PT Chevron in Pasirwangi District - Garut Regency, the labor productivity $(\mathrm{Y} / \mathrm{L}$ versus $\mathrm{K} / \mathrm{L}$ ) was greater than the related autonomic provincial economy (Amrullah, 2006, Soelistijo et al, 2010). It looks likely that there is positive 
induced influence on the local labor productivity in business or self-enterprising. In this case, the existence of utilizing local labor in the related company or using final demand (such as food, local products and so on) of the company in the form of several types of commodities and services from the local community constitutes positive impact on the increasing local labor productivity.

Somehow, the central point of development is human and all of concerning on his or her behavior. Since human who owns innovative power and high S\&T content synchronized with comprehensive management then it could be expected that human being would be more productive and be self-reliant to meet his or her live needs physically as well as spiritually.

In the context of Wawasan Nusantara outlook constituting as the Indonesian people "lebensraum" which is consisted of land (one third large of the state region) and water or sea (two third large of the state region) constitutes one region country of the Republic of Indonesia in which contains natural resources $(\mathrm{R})$. To transfer the natural resources into economic capital and then toward social capital for the nation, creative people who has high content of $\mathrm{S} \& \mathrm{~T}$, art and culture/religion (belief and faith to God) is obviously required. If Japanese people has the highest content of engineer density in the world, South Korean people has highest content of $\mathrm{Ph} \mathrm{D}$ or doctorate density in the world with the condition of low content of domestic natural resources could have the leading economy, then Indonesia owns large quantity of people and natural resources it is thought that by using correct management excellence (culture and strategy) Indonesia could obviously be expected to be excellent nation in the future of globalization era. After World War II, the people of Japan and Korea are the same with the Indonesian people just had zero economic capital. Not more than fifty years later Japan and Korea have been as self-reliant people in term of supervising S\&T with high culture. The Indonesian people should learn to them together with all of their low profile behavior. We together are to be and able to be, why not.

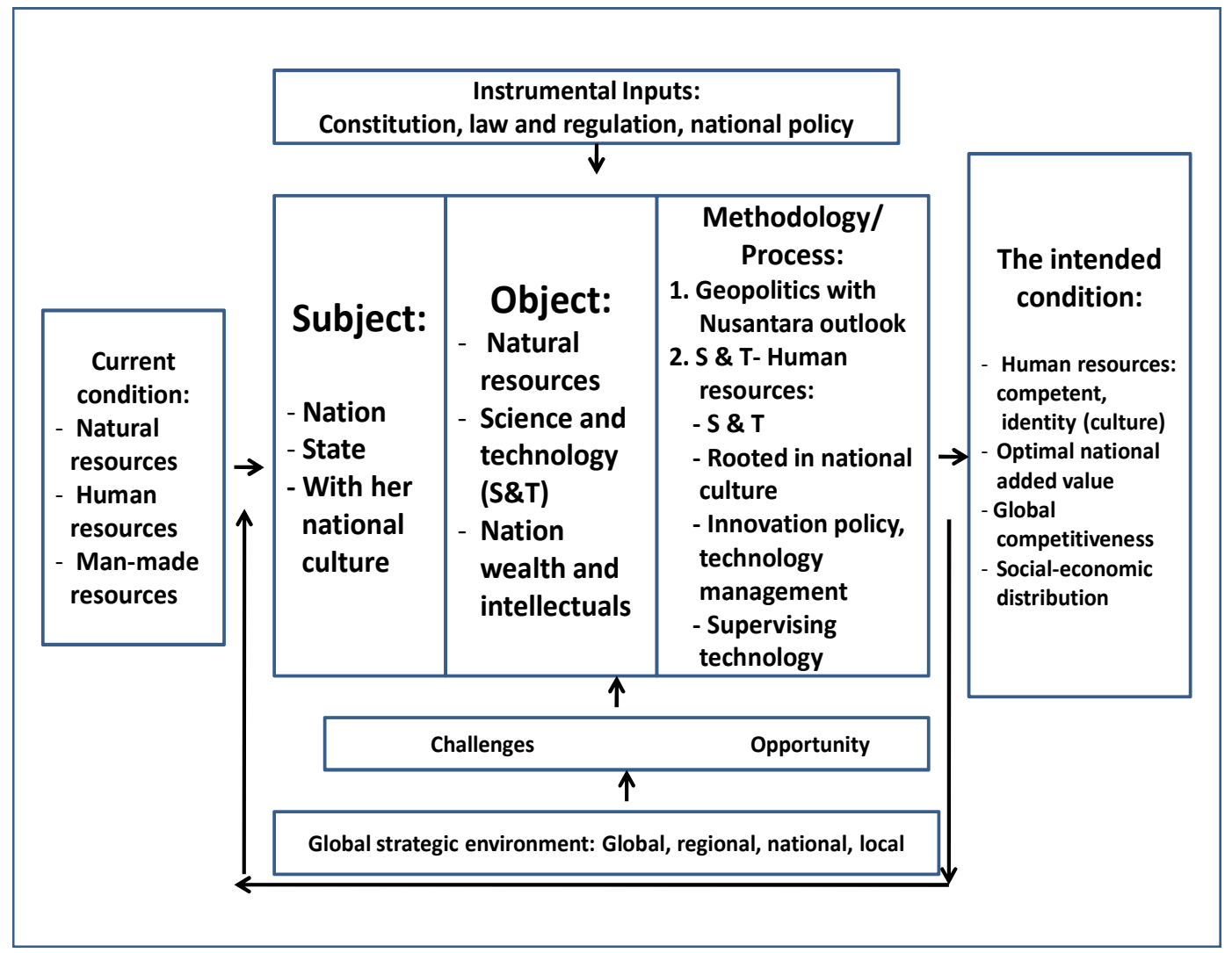

Figure 4.1. Mindset of interaction between geopolitics - science and technology-competitiveness in developing natural resource in Indonesia

\section{Concluding Remarks}

In principle, in the process of techno-economic transformation of the Indonesian natural resources carried out by the competent human capital, a grand concept and strategy is absolutely required based on geopolitics and other strategic factors such as science and technoloy and global competitiveness.
Within the understanding of geopolitics based on Nusantara outlook, with paying attention on strategic environment either at the level of global, regional, national or local, Indonesia should seriously endeavor supervising and developing S\&T rooted on the Indonesian people culture as one of the most important means for the purpose of creating national productivity jump in the frame of resulting national output with highly qualified national added value and high global competitiveness toward 
achieving national wealth and security at the utmost including the whole human universally within eternal world peace (Figure 4.1).

In the meantime genuine nation's human being are required as productive people with fully innovative and creativity, reliable mental and noble morals. At the level of Nusantara outlook, the understanding of social-economics distribution seems to have a meaning for the benefit of the humankind prosperity at the utmost, and not in the meaning of an orthodox geopolitics.

Moreover, going down to earth, the competent human capital (completed with science and technology and culture) could be able to apply integrated multiple management of natural resources in the fields of intensification of inventory, diversification, conservation and expansion or distribution to proceed sustainable development based on the strategy of pro-growth, pro-equity, pro-environment, and pro-poor toward creating wealth, intelligence and peacefulness of the people.

"Resources are limited, but creativity is unlimited!!!"

(Pohang Steel Corporation, Pohang, Korea).

"Try not just to be a man of success, but try to be a man of value". (Metro TV).

\section{References}

[1] A. Amrullah, Kajian peran PT INCO (Tbk) dalam mendukung pembangunan ekonomi Kabupaten Luwu Timur - Sulawesi Selatan era otonomi daerah: Pendekatan interindustri. Tesis Program Studi Rekayasa Pertambangan, Institut Teknologi Bandung. Thesis of Study Program of Mining Engineering, Institute of Technology Bandung), 2006.

[2] Anonymous (a), Natural Resources and Development, Institute for Scientific Cooperation, Tubingen, Volume 47, Federal Republic of Germany, Meier, Tottenburg, 1998.

[3] Anonymous (b), Geopolitik, Lembaga Katahanan Nasional, Jakarta. ("Geopolitics", The National Defense College, Jakarta.), 2000

[4] Anonymous (c), Globalisasi, Lembaga Katahanan Nasional, Jakarta. ( "Globalization", The National Defense College, Jakarta), 2000

[5] Anonymous (d), Pengembangan Sumber Daya Manusia, , Lembaga Katahanan Nasional, Jakarta. ('Human Resource Development", The National Defense College, Jakarta), 2000.

[6] Anonymous (e), Pengembangan IPTEK, Lembaga Katahanan Nasional, Jakarta. ("The Development of Science and Technology", The National Defense College, Jakarta), 2000 .

[7] Anonymous (f), Wawasan Nusantara, Lembaga Katahanan Nasional, Jakarta. ("The Nusantara Outlook", The National Defense College, Jakarta), 2000.

[8] Anonymous (g), Buku Tahunan Pertambangan dan Energi. Departemen Energi dan Sumberdaya Mineral, 1997-2005.

[9] Anonymous (h), 13 integrated economic development zones of Eastern Indonesia Region and 1(Sabang) integrated economic development zone of western Indonesia region. Department of Mines and Energy,1999.

[10] Anonymous (i), Teknologi Pertambangan di Indonesia. Pusat Penelitian dan Pengembangan Teknologi Mineral. Departemen Pertambangan dan energi, 1995.

[11] Anonymous (j), Master Plan Percepatan and Perluasan Pembangunan Ekonomi Indonesia (MP3EI), (Master Plan of Acceleration and Expansion of Indonesia Economic Development), Istana Bogor, 2011.

[12] A. Bressand, International Governance: Trade in Globalizing World Economy, Promethee, Paris, 1991.

[13] B.J. Habibi, Ceramah Penyusunan GBHN Repelita V. BPPT, 1988.

[14] L. Reksosumitro, Pengembangan Sumber Daya Alam, Lembaga Katahanan Nasional, Jakarta. ("The Development of Natural Resource", The National Defense College, Jakarta), 1992.

[15] R. Solow, K. Arrow, H. Chenery and B.Minhas. Capital-labor substitution and economic efficiency. Review of Economics and Statistics, 1961.

[16] U.W. Soelistijo, Several evaluation and analytical indicators of regional autonomy implementation impacts in Indonesia: Energy and mineral resource sector development. Indonesian Mining Journal vol. 15 Number 3, June 2012.

[17] U.W. Soelistijo, The Economic Evaluation of Research-Based Indonesian Coal Utilization. Indonesian Mining Journal, vol.15, Number 3, October 2012.

[18] U.W. Soelistijo, "Kronologis Kontrak Karya di Indonesia dan Usaha Pertambangan PT Freeport Indonesia (PT FI)," Prosiding Seminar Nasional Penelitian dan PKM: Sains, Teknologi, dan Ilmu Kesehatan, SNAPP Unisba Bandung, 13-14 November 2012 vol. 3 No.1 Tahun 2012..

[19] U.W. Soelistijo, A.P. Wibowo, and M. Abdullah, The contribution of low rank coal liquefaction in Indonesian economy in 2025. Proceedings of International Symposium on Earth Science and Technology 2012. September 18-19 2012, Aulka Barat Institute of Technology Bandung, Indonesia, 2012

[20] U.W. Soelistijo, "Beberapa Indikator Nilai Tambah Ekonomi Indonesia: Sektor Energi dan Sumber Daya Mineral (Several Indicators of the Indonesia Economy Added Value: Energy and Mineral Resource Sector)", Jurnal Teknologi Mineral dan Batubara vol. 9 Nomor 1, Januari 2013.

[21] U.W. Soelistijo, Pemikiran ke Arah Sistem Pertambangan Nasional, Diskusi Besar Pertambangan ITB, 18 Mei 1998, Bandung. ("A Thought Toward A National Mining System", Seminar on Mining - Institute of Technology Bandung, Mei 18, 1998, Bandung), 1998.

[22] U.W. Soelistijo, The role of energy in he Iundonesian economy 1975-2000. Masters Thesis, West Virginia University, USA, 1978.

[23] U.W. Soelistijo, Evaluation of the potential economic benefit og coal-oil substitution in the Indonesian economy: An interindustry approach. Ph.D. Dissertation, West Virginia University, USA, 1984. 
[24] U.W. Soelistijo, Manajemen Teknologi, Sespanas, LAN, Jakarta. ("Management of Technology", Agency for State Administration, Jakarta), 1990.

[25] U.W. Soelistijo, Ekonomi Regional dan Model Penerapannya: Pengembangan Sumberdaya Mineral dan Energy Dalam Rangka Otonomi Daerah di Indonesia. Pusat Penelitian dan Pengembangan Teknologi Mineral dan Batubara, Departemen Energi dan Sumberdaya Mineral, Bandung, 2003.

[26] U.W. Soelistijo, Pengembangan Sumberdaya Mineral dan Energi Sebagai Sarana Penggerak Mula Dalam Pengembangan Wilayah. Orasi Pengukuhan Ahli Peneliti Utama Bidang Teknologi Mineral, Energi dan Pengembangan Wilayah. Pusat Penelitian dan Pengembangan Teknologi Mineral dan Batubara, Departemen Energi dan Sumberdaya Mineral, 2005.

[27] U.W. Soelistijo, R. Saefudin, I. Suherman, Palamba, Economic Evaluation of the NEDO (Japan)-BPPT (Indonesia) Feasibility Study on the Indonesia Banko Coal Liquefaction, 2002. The Proceedings of the 28th International Conference on Coal Utilization \& Fuel Systems, vol. I and II. March 9-13, 2003, Sheraton Sand Key Clearwater, Florida, US Depatment of Energy, USA, 2003
[28] U.W. Soelistijo, Menuju Peningkatan Koordinasi Program Riset dan Teknologi dalam Pengembangan Sumber Daya Mineral, Rakornas Ristek VIII 12-14 Februari 12-14 Februari 1990, Jakarta. ("Toward Increasing Coordination On Research and Technology in Mineral Resource Development", National Coordination Meeting VIII 12-14 February 1990, Jakarta), 1990.

[29] U.W. Soelistijo, and H. Sembodo, Analisis program pengembangan masyarakat dari PLTP Darajat PT. Chevron di Kabupaten Garut-Jawa Barat. Proceeding Pekan Ilmiah Fakultas Teknik 2009/2010, Aula Utama Unisba, 24 Maret 2010.

[30] U.W. Soelistijo, B. Daulay, S. Soeprato, and Suganal, Coal gasification in Indonesia. Coal for the Future, Proceedings of the 33rd International Technical Conference on Coal Utilization \& Fuel Systems, June 1-5, 2008, Sheraton Sand Key, Clear Water, Florida, US Department of Energy, USA, 2008.

[31] U.W. Soelistijo, and R. Damayanti, Waste gases and particulates resulted from briquette combustion. Procedings Air Quality VIII, An International Conference on Carbon Management, Mercury, Trace Sunstances, Sx, Nox, and Particulate Matter, Crystal Gateway Marriot, Arlington, Virginia, USA, October 24-27, 2011. 